\title{
Biological Parameters Explain Why Shorter or Smaller People have Lower Cardiovascular Disease and Greater Longevity
}

\author{
Thomas T. Samaras ${ }^{1 *}$ \\ ${ }^{1}$ Reventropy Associates, 11487 Madera Rosa Way, San Diego, Ca. 92124, USA.
}

Author's contribution

The sole author designed, analyzed and interpreted and prepared the manuscript.

Article Information

DOI: $10.9734 / J S R R / 2017 / 34729$

Editor(s):

(1) Khadiga Ahmed Ismail, Parasitology Department, Faculty of Medicine, Ain Shams University, Cairo, Egypt.

Reviewers:

(1) Jeanie B. Tryggestad, University of Oklahoma Health Sciences Center, USA. (2) Hend M. Soliman, Diabetes, Endocrine \& Metabolism Paediatric Unit (DEMPU), Cairo University, Egypt.

(3) Ramachandran Muthiah, Thoothukudi Medical College Hospital, Thoothukudi, India. Complete Peer review History: http://www.sciencedomain.org/review-history/20000

\section{ABSTRACT}

Aim: To identify biological parameters that are related to the greater longevity and lower cardiovascular disease risk of shorter, lighter people.

Study Design: The study for this paper was conducted over the last 2 years but was based on papers and reports published over the last 40 years, which is when the author started studying the impact of body size on health and longevity. It was decided that the research would focus on how body size affects human health, mortality from chronic diseases and longevity. Human body size factors were height, weight and body mass index. Biological parameters included serum levels of insulin, IGF-1, and adiponectin. Other types of parameters included: blood pressure, the FOXO3 gene, left ventricular mass, telomeres, and DNA damage.

Methodology: Numerous biological parameters were identified by reviewing papers and notes taken over 40 years. These parameters were identified in relation to how height, weight and body mass index impact our health or longevity. Approximately, 5000 papers and reports were reviewed and parameters affecting our health and longevity were recorded.

Results: A list of 36 biological parameters and related factors was created that shows how each parameter is related to one or more body size factors (height, weight or body mass index). In 
addition, undesirable changes in parameters were identified in relation to the increase in height, weight, or body mass index.

Conclusions: Reduction in height, weight, and body mass index is related to improved biological parameters and explains why many studies find shorter, lighter people tend to have delayed incidence of chronic diseases and live longer. However, poor nutrition, excess weight, smoking, genetics, and socioeconomic (SES) status can affect biological parameters independent of body size characteristics.

Keywords: Aging; biological parameters; body mass; body mass index; cardiovascular disease; height/stature; longevity; telomeres.

\section{INTRODUCTION}

The concept that smaller body size may be related to greater longevity has been espoused by many scientists and is gaining support among various types of researchers based on recent findings in the public and scientific domains. For example, The University of Glasgow issued a news release that stated: "A study looking at how DNA changes with body size may help scientists to explain why taller individuals tend to have shorter lives" [1]. Another news release from Columbia University Medical Center stated: "Short people have several health advantages over tall people, including ...... longer life expectancy" [2]. The Director of the Aging and Longevity Research Laboratory at Southern Illinois University also stated that smaller body size has many benefits in terms of greater health and longevity [3].

While scores of longevity, survival and mortality studies support these observations, many (not all) mortality studies have found that taller people have lower mortality rates from all-causes and cardiovascular disease (CVD) [4]. However, unlike most longevity, survival and centenarian studies, many epidemiological mortality studies do not cover the entire age range of the subjects studied [5]. An exception is Waaler's study that tracked mortality till death and found that up to 70 years of age, tall men had lower mortality rates [6]. However, between 70 and 85 years of age, men over $184 \mathrm{~cm}$ had a higher mortality rate compared to men between 170 and $184 \mathrm{~cm}$. This paradoxical pattern is probably related to the fact that after 70 years of age over $70 \%$ of deaths are due to age-related chronic diseases. In contrast, most deaths before 60 years of age are primarily due to accidents, infections, suicides, congenital defects, etc. and death before 70 years of age is considered premature.

In contrast to mortality studies, almost all human longevity studies have found shorter people live longer, including $\mathrm{He}$ et al., Salaris et al., Vasto et al., Holzenberger et al., Miller, Samaras, Willcox et al., and Chan et al. [7-16]. Most of these studies were based on deceased populations in Ohio, Spain, Sardinia, Okinawa, and California. In addition, several survival studies have found shorter people tend to reach advanced ages (Maier et al., van Heemst et al., Wilhelmsen et al., and Rantanen et al. [16-19]).

Another paper (Mueller and Mazur) reported on two cohorts of West Point officers who graduated in 1925 and 1950 [20]. These officers were tracked after they retired. They had at least 20 years of active service and were free of any disabilities. The two cohorts consisted of about 900 men tracked up to mid 2008. The researchers found that the taller half of the 1925 and 1950 cohorts experienced higher mortality in the 60 and over age group. An important part of the study was that the officers represented a highly homogeneous background in ethnicity, economic background and lifestyle during their careers.

Populations with the highest percentage of centenarians in the world are almost always short when compared to northern Europeans; e.g., Okinawa, Japan; Bama, China; Nicoya, Costa Rica; Sardinia, Italy; and Ikaria, Greece. (No height data were found for Nicoya or Ikaria, but the populations of Costa Rica and Greece were relatively short when these centenarians were in their youth.)

Additional support for the advantages of smaller body size comes from comparing males and females. For example, American males are 9\% taller than females and have a $9 \%$ shorter life expectancy $[21,22]$. Shorter females also have lower CVD vs. men in most parts of the industrialized world. In addition, Brown-Borg et al. found that dwarf male mice lived substantially longer than their normal size female siblings [23]. Miller also found when he compared men and 
women of the same height, they had about the same longevity [11]. The relationship between height and CVD is more controversial. However, there are many examples of shorter people having lower CVD/coronary heart disease (CHD) than taller ones [5]. In some pre-Western populations, CHD and stroke were found to be zero.

Animal longevity research has also strongly supported the observation that smaller individuals are longer-lived than bigger individuals within the same species. Studies of mice, rats, and dogs have provided extensive support over the years for both heart disease and longevity being lower in shorter or smaller animals [4]. Based on many mammalian species, Promislow found that as individuals within a species get larger, their mortality rate increases [24]. They also found that when the female is the larger of the species, the mortality rate is higher for females. Moore and Wilson also found similar results. In addition, they found levels of parasites increased with body size [25].

For the preceding longevity studies to make sense, there should be biological factors that explain why shorter, smaller bodies promote greater longevity. The purpose of this report is to summarize 36 biological parameters that support the lower CVD and greater longevity of shorter or smaller humans who also have healthful nutrition and a good environment. These parameters include reduced cell replication, DNA damage, blood pressure, left ventricular mass (LVM), mechanistic target of rapamycin (mTOR), insulin and insulin-like growth factor-1 (IGF-1). Other benefits include greater adiponectin, forkhead box 03 (FOXO3) genotype and sex hormone binding globulin (SHBG).

\section{MATERIALS AND METHODS}

The material for this study is based on over 5000 papers and reports dealing with human body size, nutrition, chronic disease and longevity. These papers and reports were collected over the last 40 years and provided information on various biological parameters discussed in this paper. In addition, PubMed was searched for biological parameters related to body size, such as height, weight and body mass index (BMI). The internet was also searched for possible sources of information on body size and biological parameters.

Identification of subjects as shorter or smaller in the studies used for this review applies to the cohorts described in the individual studies. Thus, body size is relative to the specific population examined; e.g. US, European, Asian or African.

\section{RESULTS}

Thirty-six biological parameters or factors were identified and are presented in Table 1 $[3,5,7,16,26-144]$. A separate column identifies body size factors, such as height, weight and body mass index (BMI) related to the parameter. A third column describes the harmful effects on health due to undesirable changes in these parameters. The sources of information for each parameter are listed in the last column.

The table covers a wide variety of parameters/factors that favor smaller body size. These include longer telomeres, lower DNA damage, lower left ventricular mass, longevity genes, lower C-reactive protein, lower insulin and insulin-like growth-1 (IGF-1) hormone. Other parameters favoring the hearts and longevity of smaller people include lower mTOR, higher adiponectin, and lower homocysteine. Other factors include higher heart pumping efficiency and lower incidence of atrial fibrillation and venous thromboembolism.

The parameters/factors identified in Table 1 may change in the future as more research is focused on the ramifications of increasing body size. Detailed information on the methodology and analysis of findings on individual parameters/factors is available from the appropriate reference sources.

The trend lines or mortality rate increases for various parameters are covered in the individual references given. Mortality generally increases progressively with undesirable changes in various parameters. A few examples are given next.

Fontana and $\mathrm{Hu}$ [64] found that there was a strong linear increase in mortality with increases in $\mathrm{BMI}$ for various chronic diseases. Cardiovascular disease increased by $14 \%$ per BMI point increase. All-cause mortality has also been found to increase by $\sim 10 \%$ per BMI point increase.

A study [85] found as C-reactive protein levels increased there were proportional increases in all-cause mortality and ischemic heart attacks. For example, all-cause mortality ranged from 
hazard ratio $(\mathrm{HR})$ of 1 for $<5 \mathrm{mg} / \mathrm{L}$ to a $\mathrm{HR}$ of $>3$ for $>80 \mathrm{mg} / \mathrm{L}$.

Mendall et al. [80] found that C-reactive protein levels increased with BMI and height and correlated with increased mortality from CHD and all-causes.

Giovannelli et al. [45] found that oxidative DNA damage increased with height. The damage was expressed as the \% of DNA in tail. The damage increased from $3.28 \%$ for a height of $148-164.5$ $\mathrm{cm}$, to $4.45 \%$ for $165-173 \mathrm{~cm}$ and to $6.08 \%$ for $173.5-197.5 \mathrm{~cm}$.

\section{DISCUSSION}

Table 1 shows the relationships among biological parameters, body size, CVD, chronic diseases and longevity based on the assumption that we are comparing short and tall humans of the same proportions and lifestyles. Obviously, on an individual basis, many factors can alter the results shown in Table 1. Early nutrition promotes growth and increases in body size. However, once adulthood is attained, a larger body requires more food than a smaller one and thereby promotes undesirable increases in the levels of mTOR, insulin, IGF-1, etc.

It is important to note that height is less than $10 \%$ of the longevity picture and many other factors can affect one's longevity. For example, a taller person may be at lower risk of undesirable changes in biological parameters if he or she has a low weight for their height, higher socioeconomic (SES) status, eats a healthier diet, doesn't smoke, exercises regularly and is social connected. Genetic factors can also affect results.

Table 1. Biological parameters related to shorter, smaller body size that reduce chronic diseases and increase longevity

\begin{tabular}{|c|c|c|c|}
\hline Biological parameter & $\begin{array}{l}\text { Beneficial } \\
\text { anthropomorphic factors } \\
\text { related to biological } \\
\text { parameter }\end{array}$ & $\begin{array}{l}\text { Harmful ramifications of } \\
\text { greater or smaller } \\
\text { parameter }\end{array}$ & $\begin{array}{l}\text { Reference } \\
\text { sources }\end{array}$ \\
\hline $\begin{array}{l}\text { Longer } \\
\text { telomeres }\end{array}$ & Lower height, weight, \& BMI & $\begin{array}{l}\text { Fewer potential cell } \\
\text { replications available at } \\
\text { older ages due to faster } \\
\text { telomere attrition. Unhealthy } \\
\text { centenarians have shorter } \\
\text { telomeres compared to } \\
\text { healthy centenarians. } \\
\text { Shorter telomeres are } \\
\text { related to cardiovascular } \\
\text { aging, type } 2 \text { diabetes \& } \\
\text { reduced longevity. }\end{array}$ & $\begin{array}{l}16,26-28 \\
34-39,40- \\
43\end{array}$ \\
\hline $\begin{array}{l}\text { Lower stem cell } \\
\text { exhaustion }\end{array}$ & Lower height \& weight & $\begin{array}{l}\text { Higher erosion reduces } \\
\text { longevity due to lost ability } \\
\text { to replace damaged cells. }\end{array}$ & 29,39 \\
\hline Lower DNA damage & Lower height \& BMI & $\begin{array}{l}\text { Increased height \& BMI } \\
\text { increases total daily energy } \\
\text { expenditure \& food intake } \\
\text { which damage DNA and } \\
\text { promote aging }\end{array}$ & $44-46$ \\
\hline $\begin{array}{l}\text { Lower left ventricular } \\
\text { mass (LVM) }\end{array}$ & Lower height, weight \& BMI & $\begin{array}{l}\text { Higher LVM is a risk factor } \\
\text { for CVD \& all- cause } \\
\text { mortality independent of } \\
\text { other risk factors. }\end{array}$ & $47-51$ \\
\hline $\begin{array}{l}\text { Higher sex hormone } \\
\text { binding globulin } \\
\text { (SHBG) }\end{array}$ & Lower height, weight \& BMI & $\begin{array}{l}\text { Lower levels of sex } \\
\text { hormone binding globulin } \\
\text { are related to increased risk } \\
\text { of cancer, cardiovascular } \\
\text { disease and type } 2 \\
\text { diabetes. }\end{array}$ & $52-56$ \\
\hline
\end{tabular}


Table 1. Biological parameters related to shorter, smaller body size that reduce chronic diseases and increase longevity (continued)

\begin{tabular}{|c|c|c|c|}
\hline Fewer cells & Lower weight \& BMI & $\begin{array}{l}\text { More cells due to larger } \\
\text { body size mean higher risk } \\
\text { of cancer because of } \\
\text { greater exposure to toxins, } \\
\text { carcinogens \& radiation. }\end{array}$ & $\begin{array}{l}7,36,39,57- \\
60\end{array}$ \\
\hline Lower body mass & Lower height and BMI & $\begin{array}{l}\text { Body mass is strongly } \\
\text { correlated with height and } \\
\text { is related to increased } \\
\text { chronic disease, mortality } \\
\text { and reduced longevity in } \\
\text { humans and animals. }\end{array}$ & $\begin{array}{l}3,5,16,24 \\
25,34,39,61\end{array}$ \\
\hline $\begin{array}{l}\text { Lower blood } \\
\text { pressure }\end{array}$ & Lower height, weight \& BMI & $\begin{array}{l}\text { Higher BP r with } \\
\text { hypertension and CVD }\end{array}$ & $30-32,64-72$ * \\
\hline Fewer free radicals & Lower height \& weight & $\begin{array}{l}\text { A larger body requires } \\
\text { more food that produces } \\
\text { more free radicals. More } \\
\text { free radicals increase } \\
\text { damage to DNA, cell } \\
\text { structures and } \\
\text { components, and CV } \\
\text { system. }\end{array}$ & $34,45,73,74$ \\
\hline $\begin{array}{l}\text { Increased incidence } \\
\text { of Laminin, Alpha } 5 \\
\text { rs4925386-T allele }\end{array}$ & Lower height & $\begin{array}{l}\text { The occurrence of this } \\
\text { Genotype is related to } \\
\text { longer longevity, especially } \\
\text { after } 85 \text { years of age }\end{array}$ & 75 \\
\hline $\begin{array}{l}\text { Lower Pulse Wave } \\
\text { Velocity (PWV) }\end{array}$ & $\begin{array}{l}\text { Lower height, weight \& BMI } \\
\text { (a decrease in PWV with } \\
\text { increasing height has been } \\
\text { found in a few studies.) }\end{array}$ & $\begin{array}{l}\text { Higher PWV is an } \\
\text { independent predictor of } \\
\text { CVD, stroke, \& all-cause } \\
\text { mortality in healthy people }\end{array}$ & $48,76,77$ \\
\hline
\end{tabular}

Table 1. Biological parameters related to shorter, smaller body size that reduce chronic diseases and increase longevity (continued)

\begin{tabular}{|c|c|c|c|}
\hline $\begin{array}{l}\text { Larger organs in } \\
\text { relation to weight }\end{array}$ & Lower height & $\begin{array}{l}\text { Smaller organs in relation to body } \\
\text { mass have lower functional } \\
\text { capacity; Exceptions: heart and } \\
\text { lungs are proportional to weight }\end{array}$ & 78,79 \\
\hline $\begin{array}{l}\text { Lower C-reactive } \\
\text { protein (CRP) }\end{array}$ & $\begin{array}{l}\text { Lower height, weight \& } \\
\text { BMI }\end{array}$ & $\begin{array}{l}\text { Higher CRP levels promote CVD, } \\
\text { cancer, type } 2 \text { diabetes and all- } \\
\text { cause mortality (one study } \\
\text { showed a r with BMI but a -r with } \\
\text { height in older subjects) }\end{array}$ & $43,80-87$ \\
\hline Lower BMI & Lower weight for height & $\begin{array}{l}\text { Assuming same body types are } \\
\text { compared: } \\
\text { Chronic disease \& all-cause } \\
\text { mortality increase in a strong } \\
\text { linear trend with increasing BMI } \\
\text { BMI r with height in children } \\
\text { A number of studies have found a } \\
\text { decreasing BMI within the normal }\end{array}$ & $\begin{array}{l}33,64-66,80 \text {, } \\
89-93\end{array}$ \\
\hline
\end{tabular}


range increases mortality. In view of the many undesirable trends of most biological parameters vs. $\mathrm{BMI}$, it appears these findings are confounded by other factors. The WCRF report (based on review of about 7000 papers and reports) recommends keeping BMI low (21 to 23$)$.

Table 1. Biological parameters related to shorter, smaller body size that reduce chronic diseases and increase longevity (continued)

\begin{tabular}{|c|c|c|c|}
\hline $\begin{array}{l}\text { Lower insulin-like growth } \\
\text { factor-1 (IGF-1) }\end{array}$ & $\begin{array}{l}\text { Lower height, weight, \& } \\
\text { BMI (Some studies show } \\
\text { a increase in IGF-1 with } \\
\text { increasing BMI over the } \\
\text { normal BMI range but a } \\
\text { decrease in IGF-1 with a } \\
\text { BMI in the obesity } \\
\text { range..) }\end{array}$ & $\begin{array}{l}\text { IGF-1 -r longevity. } \\
\text { IGF-1 is also related to } \\
\text { cancer; Laron dwarfs in } \\
\text { Ecuador have low IGF-1 } \\
\text { levels and no deaths } \\
\text { from cancer or diabetes. }\end{array}$ & $\begin{array}{l}3,16,17,61 \\
94-99\end{array}$ \\
\hline Lower insulin & $\begin{array}{l}\text { Lower height, weight \& } \\
\text { BMI }\end{array}$ & $\begin{array}{l}\text { Lower insulin levels are } \\
\text { related to greater } \\
\text { longevity }\end{array}$ & $\begin{array}{l}16,17,69,100- \\
104\end{array}$ \\
\hline $\begin{array}{l}\text { Higher insulin-like growth } \\
\text { factor binding protein-1 } \\
\text { (IGFBP-1) }\end{array}$ & $\begin{array}{l}\text { Lower weight, BMI, \& } \\
\text { height (after } 65 \text { yr of } \\
\text { age) }\end{array}$ & $\begin{array}{l}\text { Lower IGFBP-1 is related } \\
\text { to higher cancer, CVD, \& } \\
\text { type } 2 \text { diabetes }\end{array}$ & $98,105,106$ \\
\hline Lower parasites & Lower body mass & $\begin{array}{l}\text { Body parasites increase } \\
\text { with increasing body } \\
\text { mass independent of sex } \\
\& \text { are related to } \\
\text { increased mortality }\end{array}$ & 25 \\
\hline $\begin{array}{l}\text { Higher FOXO3 gene } \\
\text { expression }\end{array}$ & Shorter height & $\begin{array}{l}\text { Lower levels of FOXO3 } \\
\text { gene are related to CVD } \\
\text { and lower longevity }\end{array}$ & 7,107 \\
\hline $\begin{array}{l}\text { Lower mechanistic } \\
\text { (mammalian) target of } \\
\text { rapamycin (mTOR) }\end{array}$ & Lower weight \& BMI & $\begin{array}{l}\text { Higher levels of mTOR } \\
\text { promote cell replication, } \\
\text { growth and reduce } \\
\text { longevity; mTOR also } \\
\text { promotes chronic } \\
\text { disease }\end{array}$ & $3,108-110$ \\
\hline Higher adiponectin & $\begin{array}{l}\text { Lower weight \& BMl; } \\
\text { lower height only in } \\
\text { childhood }\end{array}$ & $\begin{array}{l}\text { Lower adiponectin is a } \\
\text { risk factor for heart } \\
\text { disease and increases } \\
\text { the risk of other chronic } \\
\text { diseases. Also reduces } \\
\text { longevity. }\end{array}$ & $111-116$ \\
\hline Lower Cystatin-C & Lower height \& weight & $\begin{array}{l}\text { Higher levels related to } \\
\text { increased risk of CVD \& } \\
\text { kidney disease }\end{array}$ & 117,118 \\
\hline Lower creatinine & Lower height \& weight & $\begin{array}{l}\text { Higher levels related to } \\
\text { increased risk of CVD \& } \\
\text { kidney function or } \\
\text { disease }\end{array}$ & 117,118 \\
\hline
\end{tabular}


Table 1. Biological parameters related to shorter, smaller body size that reduce chronic diseases and increase longevity (continued)

\begin{tabular}{|c|c|c|c|}
\hline $\begin{array}{l}\text { Lower food toxin } \\
\text { intake }\end{array}$ & Lower weight \& BMI & $\begin{array}{l}\text { Higher weight is } r \text { with } \\
\text { increased intake of food and } \\
\text { related toxins that damage cells. }\end{array}$ & 62,119 \\
\hline $\begin{array}{l}\text { Higher heart } \\
\text { pumping efficiency }\end{array}$ & $\begin{array}{l}\text { Lower height, weight, \& } \\
\text { BMI }\end{array}$ & $\begin{array}{l}\text { Larger hearts pump a lower } \\
\text { percentage of blood out of left } \\
\text { ventricle }\end{array}$ & 47,120 \\
\hline $\begin{array}{l}\text { Lower homocysteine } \\
\text { (Hcy) }\end{array}$ & $\begin{array}{l}\text { Lower weight \& BMI (not } \\
\text { all studies show } r \text { with } \\
\text { body weight or } \mathrm{BMI} \text { ) }\end{array}$ & $\begin{array}{l}\text { Higher weight is } r \text { with higher } \\
\text { Hcy levels which promote CVD } \\
\text { and telomere attrition }\end{array}$ & $35,121-123$ \\
\hline Higher HDL & $\begin{array}{l}\text { Lower height, weight, \& } \\
\text { BMI }\end{array}$ & $\begin{array}{l}\text { Lower levels are related to heart } \\
\text { problems; some studies show } \\
\text { shorter people have lower HDL } \\
\text { but this appears to be due to } \\
\text { higher BMl, lower economic } \\
\text { status or other factors. }\end{array}$ & $\begin{array}{l}33,66,82, \\
100,124-126\end{array}$ \\
\hline $\begin{array}{l}\text { Lower triglycerides } \\
\text { (TG) }\end{array}$ & $\begin{array}{l}\text { Lower height, weight, \& } \\
\text { BMI }\end{array}$ & $\begin{array}{l}\text { Higher levels are related to } \\
\text { heart problems }\end{array}$ & $\begin{array}{l}65,66,69,88, \\
100\end{array}$ \\
\hline Lower ApoB & Lower BMI & $\begin{array}{l}\text { Higher levels of ApoB are } \\
\text { related to heart disease \& } \\
\text { metabolic syndrome, especially } \\
\text { a high ratio of ApoB/ApoA-1 }\end{array}$ & 88,127 \\
\hline Higher ApoA-1 & Lower BMI & $\begin{array}{l}\text { A lower level of } A p o A \text { and a } \\
\text { higher ratio of } A p o B / A p o A-1 \text { are } \\
\text { related to greater heart disease } \\
\& \text { metabolic syndrome }\end{array}$ & 88,127 \\
\hline
\end{tabular}

Table 1. Biological parameters related to shorter, smaller body size that reduce chronic diseases and increase longevity (continued)

\begin{tabular}{|c|c|c|c|}
\hline $\begin{array}{l}\text { Lower low-density } \\
\text { lipoprotein (LDL) }\end{array}$ & $\begin{array}{l}\text { Lower BMI, weight } \\
\text { \& height }\end{array}$ & $\begin{array}{l}\text { Heart is damaged by higher } \\
\text { LDL. As BMI increases, LDL } \\
\text { increases as well. } \\
\text { (There are conflicting findings } \\
\text { on height and LDL; however, } \\
\text { these stand in contrast to the } \\
\text { low levels of LDL in short } \\
\text { hunter-gathers.) }\end{array}$ & $\begin{array}{l}65,69,88,100 \\
129-131\end{array}$ \\
\hline Lower glucose & Lower BMI & $\begin{array}{l}\text { Glucose levels > } 83 \mathrm{mg} / \mathrm{dl} \\
\text { increase CHD, stroke, type } 2 \\
\text { and all-cause mortality. } \\
\text { Note: shorter height appears } \\
\text { to increase or have no effect } \\
\text { on glucose levels }\end{array}$ & $\begin{array}{l}65,66,88,132- \\
135\end{array}$ \\
\hline Lower fibrinogen & Lower BMI & $\begin{array}{l}\text { Higher fibrinogen is related to } \\
\text { heart problems. }\end{array}$ & 88,139 \\
\hline $\begin{array}{l}\text { Lower atrial fibrillation } \\
\text { (AF) }\end{array}$ & Lower height & $\begin{array}{l}\text { Higher AF increases risk of } \\
\text { stroke }\end{array}$ & 140,141 \\
\hline $\begin{array}{l}\text { Lower venous } \\
\text { thromboembolism (VTE) }\end{array}$ & Lower height \& BMI & $\begin{array}{l}\text { Higher VTE increases risk of } \\
\text { death in men }\end{array}$ & 142,143 \\
\hline $\begin{array}{l}\text { Lower Total Cholesterol } \\
\text { (TC) }\end{array}$ & Lower BMI \& height & $\begin{array}{l}\text { Higher TC increases risk of } \\
\text { CVD }\end{array}$ & $\begin{array}{l}65,66,69,88 \\
144\end{array}$ \\
\hline
\end{tabular}


The findings presented in Table 1 are consistent with a review of eight types of studies that support the "smaller lives longer" thesis. These eight areas are: (1) within a species smaller individuals live longer, (2) animal studies show caloric restriction (CR) produces smaller animals that live longer, (3) smaller females live longer than males, (4) US studies show that as ethnic groups get taller, age-adjusted all-cause mortality increases; e.g., Asians have the lowest mortality vs. Blacks and Whites who are the tallest and have the highest mortality. (However, subsequent generations of Asians may lose much of the longevity benefits of their parents and grandparents.) Other types of studies supporting the increased longevity of shorter or smaller people include (5) survival studies, (6) centenarian body size, (7) life expectancy, and (8) research based on deceased populations [5]

It is important to keep in mind that the findings presented here are based on the assumption that we are comparing similar body-type people. Obviously, tall, thin people would have different parameters compared to short, overweight people. For example, many epidemiological studies find taller men have lower mortality rates than shorter men. However, insurance findings from the 1979 Build Study found that shorter men were more overweight than taller men [21]. When they compared tall and short men with the same degree of overweight, the shorter men had a slightly lower mortality.

Socioeconomic status is biased towards taller people who may average a 5-year longer life expectancy. However, few studies adjust accurately for many SES confounders [21,145]. SES factors favoring taller people include a higher standard of living, better medical care and substantially lower stress. A higher percentage of shorter people tend to be in lower SES. They tend to be heavier in proportion to their heights and suffer from higher blood pressure and glucose levels. They also smoke more and don't exercise as much during their free time. Another disadvantage is that their diet is not as healthful as higher SES individuals. Their diets tend towards fast foods that are high in calories, animal protein, fats, and salt. Another problem is that childhood infections or other illnesses tend to stunt growth and some of these diseases can have a health impact in adulthood. Another confounder that is rarely considered is that shorter people born in lower SES classes are negatively impacted in adult health although they may have risen to higher SES levels. A study of
US West Point graduates provides an exception to most of the preceding confounders. Mueller and Mazur [20] studied 900 West Point officers who had retired and were 50 or more years of age. These officers represented a similar family background and life history and thus provided a less biased view of shorter people within this cohort. The researchers found that after 60 years of age, shorter officers had a lower mortality rate. Another study [30] found when the benefits of higher SES are removed, taller low SES people had $~ 40 \%$ higher risk of heart attacks compared to low SES shorter people [30].

The confounders just discussed may be changing. For example, some reports have found that taller people are gaining weight at a faster rate than shorter individuals. If this change continues, it could alter the confounders that are related to shorter and taller people.

Based on the traditional viewpoint that taller height is related to lower mortality, it seems reasonable to assume that tall people would dominate in centenarian studies. However, it is just the opposite. Although some people over 183 $\mathrm{cm}$ reach 100 years of age, the vast majority of centenarians are short and lean [15].

Another confounder involves low birth weight individuals who experience catch-up growth during early childhood. Studies show these individuals tend to remain somewhat shorter than normal weight peer group and have higher risk for chronic diseases in adulthood $[3,32]$. School children that are shorter than their peers may also suffer from pathological conditions that predict adult health problems with shorter height being a consequence of the pathological conditions.

Even when cohorts with the same BMls are compared, this can lead to incorrect results. Taller populations should have BMls that are equal to the percentage difference in height between the two cohorts. For example, a $10 \%$ taller cohort should have a $10 \%$ higher BMI compared to the shorter cohort. The reasons for taller people having a higher BMI with the same body proportions are described by Samaras [33].

Research as to whether height is an independent factor vs. BMI is limited. However, a study of baseball players with virtually the same BMls $\left(\sim 23 \mathrm{~kg} / \mathrm{m}^{2}\right)$ but 10 different height groupings $(165-188 \mathrm{~cm})$ showed a substantial decline in lifespan for increasing height groupings [146]. A 
second cohort of baseball players with a heavier BMI $\left(26 \mathrm{~kg} / \mathrm{m}^{2}\right)$ also showed an inverse trend between height and average lifespan with a constant BMI throughout the height range of 165$188 \mathrm{~cm}$. (The grouping with the lower BMI had a higher overall lifespan compared to the higher BMI group for the same range of height categories.)

In addition, there were other findings that showed the percent height increase and decrease in longevity was inversely related [146]: A partial sample follows:

Taller US males vs. shorter females: men 9\% taller and $9 \%$ shorter life expectancy

Taller US Asian males vs. shorter females: men $8 \%$ taller and $8 \%$ shorter life expectancy Taller baseball players vs. shorter players: $4 \%$ taller players had $4 \%$ shorter life spans.

Taller US veterans vs. shorter veterans: $6 \%$ taller veterans had 7\% lower life spans

Other findings involved loss of longevity with increasing height [146]. Seven populations were analyzed. They varied from .35 to .63 years per $\mathrm{cm}$ of increased height. The average for seven populations was .5 year per $\mathrm{cm}$ of increased height. Data from three other researchers showed the same value $(.5$ year $/ \mathrm{cm})$ for populations of Ohio, Sweden and Finland [12]. It is unlikely that a recurring figure of .5 year $/ \mathrm{cm}$ between height and longevity would be due to coincidence.

\section{CONCLUSIONS}

The findings in this paper provide evidence that the levels of many biological parameters or factors are related to shorter, smaller bodies. Desirable changes to these levels tend to be associated with lower CVD risk, better health and greater longevity in smaller bodies based on the assumption that shorter height or low body weight was not caused by childhood health problems. For some biological parameters, higher levels are harmful; for others, lower levels are harmful. However, differences in an individual's life history, body proportions, nutrition and genetics can provide conflicting results.

\section{COMPETING INTERESTS}

Author has declared that no competing interests exist.

\section{REFERENCES}

1. University of Glasgow Research News. Bigger is not better when it comes to lifespan. Wed. 02 Dec 2015.

Available:http://www.gla.ac.uk/research/ne ws/headline 436036 en.html.

2. Columbia University Medical Center Newsroom, Lung transplant criteria biased against shorter patients. 16 Nov 2015. Available:newsroom.cumc.columbia.edu/bl og/2015/11/16/lung-transplant...

3. Bartke A. Healthy aging: Is smaller better?-A mini-review. Gerontology. 2012;58(4):337-343.

DOI:10.1159/000335166.

4. Samaras TT. Body height and its relation to chronic disease and longevity. In Samaras TT (ed), Human Body Size and the Laws of Scaling: Physiological, Performance, Growth, Longevity and Ecological Ramifications. New York: Nova Science Publishers. 2007;1-17:63-112.

5. Samaras TT. Evidence from eight different types of studies showing that smaller body size is related to greater longevity. JSRR 2014;3(16):2150-2160.

6. Waaler HT. Height, weight and mortality; the Norwegian experience. Acta Med Scan. 1983;Supple 679:1-50.

7. He Q, Morris BJ, Grove JS, Petrovitch H, Ross W, Masaki KH, et al. Shorter men live longer: association of height with longevity and $\mathrm{FOXO} 3$ genotype in American men of Japanese ancestry. PLoS ONE. 2014;9(5): e94385.

DOI:10.1371/journal.pone.0094385.

8. Salaris L, Poulain M, Samaras TT. Height and survival at older ages among men born in an inland village in Sardinia (Italy), 18662006. Biodemography Soc Biol. 2012; 58(1):1-13. http://dx.doi.org/10.1080/19485565.2012.6 $\underline{66118}$

9. Vasto S, Rizzo C, Caruso C. Centenarians and diet: What they eat in the Western part of Sicily. Immun Ageing. 2012;9:10.

DOI: 10.1186/1742-4933-9-10.

10. Holzenberger M, Martın-Crespo RM, Vicent D, Ruiz-Torres A. Decelerated growth and longevity in men. Arch Gerontol Geriatr. 1991;13:89-101.

11. Miller DD. Economies of scale. Challenge. 1990;33:58-61. 
12. Samaras TT. Should we be concerned over increasing body height and weight? Exp Gerontol. 2008;44:83-92.

DOI: 10.1016/j.exger.2008.02.002.

13. Samaras TT. Health risks of higher birth weight, rapid growth, early maturation and taller height. Women's Health Bull. 2015; 2(3):e26805.

14. Willcox DC, Willcox BJ, Hsueh WC, Suzuki M. Genetic determinants of exceptional human longevity: Insights from the Okinawa centenarian study. Age. 2006; 28(4):313-332.

DOI: 10.1007/s11357-006-9020-x.

15. Chan YY, Suzuki M, Yamamoto SA. Comparison of anthropometry, biochemical variables and plasma amino acids among centenarians, elderly and young subjects. $J$ Am Coll Nutr. 1999;18(4):358-365.

16. Maier $A D$, van Heemst $D$, Westendorp RGJ. Relation between body height and replicative capacity of human fibroblasts in nonagenarians. J Gerontol A Biol Sci. 2008;63:43-45.

17. Van Heemst D, Beekman M, Mooijaart SP, Heijmans BT, Brandt BW, Zwaan BJ, et al. Reduced insulin/IGF-1 signaling and human longevity. Aging Cell. 2005;4:79-85. DOI: 10.1111/j.1474-9728.2005.00148.x.

18. Wilhelmsen L, Svardsudd K, Eriksson $\mathrm{H}$, Rosengren A, Hansson PO, Welin C, et al. Factors associated with reaching 90 years of age: A study of men born in 1913 in Gothenburg, Sweden. J Intern Med. 2010; 269:441-451.

19. Rantanen T, Masaki K, He Q, Ross GW, Willcox BJ, White L. Midlife muscle strength and human longevity up to age 100 years: A 44-year prospective study among a decedent cohort. AGE. 2012; 34:563-570.

DOI: 10:1007/s11357-011-9256-y.

20. Mueller U, Mazur A. Tallness comes with higher mortality in two cohorts of US Army officers. Paper presented at the XXVI IUSSP International Population Conference. 2009;1-22.

Available:http://iussp2009.princeton.edu/pa pers/90578

21. Samaras TT, Elrick $\mathrm{H}$, Storms $\mathrm{LH}$. Is height related to longevity? Life Sci. 2003; 72:1781-1802.

DOI: 10:1016/S0024-3205(02)02503-1.

22. Samaras TT. Are $20^{\text {th }}$ - century recommendations for growth and height correct? A review. S Afr J Clin Nutr. 2009; 22(4):71-176.
23. Brown-Borg HM, Meilska KE, Bartke A. Dwarf mice and the aging process. Nature. 1996;384:33.

24. Promislow DEL. Costs of sexual selection in natural populations of mammals. Proc $R$ Soc Lond (B). 1992;247:203-210.

25. Moore SL, Wilson K. Parasites as a viability cost of sexual selection in natural populations of mammals. Science. 2002; 297:2015-218.

26. Guzzardi MA, lozzo P, Salonen M, Kajantie $E$, Erkisson JG. Rate of telomere shortening and metabolic and cardiovascular risk factors: A longitudinal study in the 1934-44 Helsinki birth cohort study. Ann Med; 2015.

DOI: 10.3109/07853890.2015.1074718.

27. Ringsby $\mathrm{TH}$, Jensen $\mathrm{H}$, Pam $\mathrm{H}$, Kvalnes $\mathrm{T}$, Boner W, Gillespie R, et al. On being the right size: increased body size is associated with reduced telomere length under natural conditions. Proc Biol Sci. 2015;282(1820). pii: 20152331.

DOI: 10.1098/rspb.2015.2331

28. Barrett ELB, Burke TA, Hammers M, Komdeur J, Richardson DS. Telomere length and dynamics predict mortality in a wild longitudinal study. Mol Ecol. 2013; 22:249-259.

DOI: $10.1111 / \mathrm{mec} .12110$.

29. Richardson RB. Age-specific bone tumour incidence rates are governed by stem cell exhaustion influencing the supply and demand of progenitor cells. Mech Ageing Dev. 2014;139:31-40.

DOI: 10.1016/j.mad.2014.06.001.

30. Osika W, Montgomery SM. Economic disadvantage modifies the association of height with low mood in the US, 2004: The disappointment paradox. Econ Hum Biol. 2008;6:95-107.

31. Samaras TT. Shorter height is related to lower cardiovascular disease risk-A narrative review. IHJ. 2013;65:66-71.

32. Singhal A, Cole TJ, Fewtrell M, Kennedy K, et al. Promotion of faster weight gain in infants born small for gestational age. Circulation. 2007;115:203-220.

DOI:10.1161/CIRCI:CIRCULATIONAHA.10 6.617811 .

33. Samaras TT. Human scaling and the body mass index. In: Samaras TT (ed). Human Body Size and the Laws of Scaling: Physiological, Performance, Growth, Longevity and Ecological Ramifications. New York: Nova Science Publishers. 2007;17-31. 
34. Rollo CD. Growth negatively impacts the life span of mammals. Evol Dev. 2002;4(1):55-61.

35. Cameron N, Demerath EW. Critical periods in human growth and their relationship to diseases of aging. Yrbk Phys Anthropol. 2002;45:159-184.

36. Stindl R. Tying it all together: telomeres, sexual size dimorphism and the gender gap in life expectancy. Med Hyp. 2004;62:151-154.

37. Valdes AM, Andrew T, Gardner JP, Kimura M, Oelsner E, Cherkas LF, et al. Obesity, cigarette smoking, and telomere length in women. The Lancet; 2005. DOI:10.1016/S0140-6736(05)66630-5.

38. Terry DF, Nolan VG, Andersen SL, Perls TT, Cawthon R. Association of longer telomeres with better health in centenarians. Journal of Gerontology: Biological Sciences 63A. 2008;8:809-812.

39. de Magalhaes JP, Faragher RGA. Cell divisions and mammalian aging: Integrative biology insights from genes that regulate longevity. BioEssays. 2008;30(6):567-578. DOI:10.1002/bies.20760.

40. Kim S, Parks CG, DeRoo LA, Chen H, Taylor JA, Cawthon RM, Sandler DP. Obesity and weight gain in adulthood and telomere length. Cancer Epidemiol Biomarkers Prev. 2009;18(3):816-20.

41. Salpea KD, Humphries SE. Telomere length in atherosclerosis and diabetes. Atherosclerosis. 2010;209(1):35-38.

DOI: $\quad 10.1016 /$ j. atherosclerosis 2009.12.021.

42. Muezzinler A, Zaineddin AK, Brenner $\mathrm{H}$. Body mass index and leukocyte telomere length in adults: A systematic review and meta-analysis. Obes Rev. 2014;15(3):192201.

43. Rode L, Nordestgaard BG, Weischer M, Bojesen SE. Increased body mass index, elevated C-reactive protein and short telomere length. J Clin Endocrinol Metab. 2014;99(9):E1671-5.

DOI: 10:1210/jc.2014-1161.

44. Loft S, Vistisen K, Ewertz M, Tjonneland A, Overvad K, Poulsen HE. Oxidative DNA damage estimated by 8hydroxydeoxyguanosine excretion in humans: influence of smoking, gender and body mass index. Carcinogenesis. 1992; 13(12):2241-2247.

DOI: 10.1093/carcin/13.12.2241.

45. Giovannelli L, Saieva C, Masala G, Testa G, Salvini S, Pitozzi V, et al. Nutritional and lifestyle determinants of DNA oxidative damage: A study in a Mediterranean population. Carcinogenesis. 2002;23(9): 1483-1489.

46. Correa C, Talon L, Pierine D, Francisqueti F, Minatel I, Santos K, Nunes V, et al. Quality of diet and body mass index are factors involved in DNA damage in human lymphocytes. The FASEB Journal. 2015;29(1):Supplement LB311.

47. De Simone G, Devereux RB, Daniels SR, Mureddu GF, Roman J, Kimball TR, et al. Stroke volume and cardiac output in normotensive children and adults. Assessment of relations with body size and impact of overweight. Circulation. 1997;95(7):1837-1843.

48. Kumaran K, Fall CHD, Martyn CN, Vijayakumar M, Stein C, Shier R. Blood pressure, arterial compliance, and left ventricular mass; no relation to small size at birth in south Indian adults. Heart. 2000;83:272-277.

49. Rodrigues SL, Pimentel EB, Mill JG. Cardiac ventricular weights recorded at the autopsy of healthy subjects who died of external causes. Arq Bras Cardiol. 2007; 88(5):252-257.

50. Rider OJ, Francis JM, Ali MK, Byren J, Clarke K, Neubauer S, Petersen SE. Determinants of left ventricular mass in obesity; a cardiovascular magnetic resonance study. J Cardiovasc Magn Reson. 2009;11(9).

DOI: 10.1186/1532-429X-11-9.

51. Bouzas-Mosquera A, Broullon FJ, AlvarezGarcia N, Peteiro J, Mosquera VX, CastroBeiras A. Association of left ventricular mass with all-cause mortality, myocardial infarction and stroke. PLoS ONE. 2012;7(9):e45570.

DOI: $10.1371 /$ journal/pone.0045570.

52. Lonning PE, Helle SI, Johannessen DC, Adlercreutz $\mathrm{H}$, Lien EA, Tally M, Ekse D, et al. Relations between sex hormones, sex hormone binding globulin, insulin-like growth factor-1, and insulin-like growth factor binding protein-1 in post-menopausal breast cancer patients. Clin Endocrinol. 1995;43(1):23-30.

53. Gates JR, Parpia B, Campbell TC, Junshi C. Association of dietary factors and selected plasma variables with sex hormone-binding globulin in rural Chinese women. Am J Clin Nutr. 1996;63:22-31.

54. Nagata C, Kabuto M, Takatsuka N, Shimizu H. Associations of alcohol, height 
and reproductive factors with serum hormone concentrations in postmenopausal Japanese women. Breast Cancer Res Treat. 1997;44:241-241.

55. Wuu J, Hellerstein S, Lipworth L, Wide L, Xu B, Yu GP, Kuper H, et al. Correlates of pregnancy oestrogen, progesterone and sex hormone-binding globulin in the USA and China. Eur J Cancer Prev. 2002; 11(3):283-93.

56. Bataille V, Perret B, Evans A, Amouyel P, Arveiler D, Ducimetiere $\mathrm{P}$, Bard JM, Ferrieres J. Sex hormone binding globulin is a major determinant of the lipid profile: the PRIME study. Atherosclerosis. 2005; 179:369-373.

57. Schmidt Nielsen K. Scaling: Why is Animal Size so Important? UK, Cambridge: University of Cambridge. 1984;90.

58. Parr T. Insulin exposure controls the rate of mammalian aging. Mech Ageing Dev. 1996;88:75-82.

59. Green J, Cairns BJ, Casabonne D. Wright FK, Reeves G, Berai V. Height and cancer incidence in the Million Women Study: Prospective cohort, and meta-analysis of prospective studies of height and total cancer risk. Lancet; 2011.

DOI: 10.1016/S1470-2045(11)70154-1.

60. World Cancer Research Fund/American Institute of Cancer Research. Food, Nutrition, Physical Activity and the Prevention of Cancer. A Global Perspective. Washington DC: AICR. 2007;229.

61. Miller RA, Austad SN. Growth and aging: why do big dogs die young? In Masoro \& Austad (ed). Handbook of the Biology of Aging $6^{\text {th }}$ edition. MA: Elsevier Academic Press. 2006;512-531.

62. Cohen DA, Sturm R. Body mass index is increasing faster among taller persons. Am J Clin Nutr. 2008;87(2):445-448.

63. Kraus C, Pavard S, Promislow DE. The Size-life span trade-off decomposed: Why large dogs die young. Amer Nat. 2013; 181(4):492-595.

DOI: $10.1086 / 669665$.

64. Fontana L, Hu FB. Optimal body weight for health and longevity: Bridging basic, clinical, and population research. Aging Cell. 2014;13:391-400.

65. Hsu-Hage BH-H, Wahlqvist ML. Cardiovascular risk in adult Melbourne Chinese. Aust J Public Health. 1993; 17:306-13.
66. Shaper AG, Wannamethee SG, Walker M. Body weight: Implications for the prevention of coronary heart disease, stroke, and diabetes mellitus in a cohort study of middle aged men. BMJ. 1997;314:1311-1317.

67. Voors AW, Webber LS, Frerichs RR, Berenson GS. Body height and body mass as determinants of basal blood pressure in children-The Bogalusa Heart Study Am J Epidemiol. 1977;106(2):101-108.

68. Falkner B, Hulman S, Kushner H. Birth weight versus childhood growth as determinants of adult blood pressure. Hypertension. 1998;31[part 1]:145-150.

69. Bavdekar A, Yajnik CS, Fall CH, Bapat S, Pandit AN, et al. Insulin resistance syndrome in 8-year old Indian children: small at birth, big at 8 years, or both? Diabetes. 1999;48(12):2422-9.

70. Lawlor DA, Najman JM, Sterne J, Williams GM, Ebrahim S, Smith GD. Associations of parental, birth, and early life characteristics with systolic blood pressure at 5 years of age. Findings from the Mater-University Study of Pregnancy and Its Outcomes. Circulation. 2004;110:2417-2423.

71. Fujita $\mathrm{Y}$, Kouda K, Nakamura H, Nishio N, Takeuchi H, Iki M. Relationhship between height and blood pressure in Japanese schoolchildren. Pediatr Int. 2010;52(5):68993.

DOI: 10.1111/j.1442-200X.2010.03093x.

72. Neuhauser HK, Thamm M, Ellert U, Hense HW, Rosario AS. Blood pressure percentages by age and height from nonoverweight children and adolescents in Germany. Pediatrics; 2010.

DOI: $10.1542 /$ peds.2010-1290.

73. Rollo CD. Technical review of molecular and physiological aspects relevant to size, free radicals, and aging. In Samaras TT (ed), Human Body Size and the Laws of Scaling: Physiological, Performance, Growth, Longevity and Ecological Ramifications. New York: Nova Science Publishers. 2007;341-357.

74. Misra MK, Sarwat M, Bhakuni P, Tuteja R, Tuteja N. Oxidative stress and ischemic myocardial syndromes. Med Sci Monit. 2009;15(10):RA209-219.

75. De Luca $M$, Crocco $P$, De Rango $F$, Passarino G, Rose G. Association of the Laminin, Alpha 5 (LAMA5) rs4925386 with height and longevity in an elderly population from Southern Italy. Mech 
Ageing Dev. 2016;pii:S0047-6374(16) 30024-0.

DOI: 10:1016/j.mad.2016.03.003.

76. Reusz GS, Cseprekal O, Temmar M, Kis E, Cherif $A B$, Thaleb $A$, et al. Reference values of pulse wave velocity in healthy children and teenagers. Hypertension. 2010;56:217-224.

77. Pizzi OL, Brandao AA, Pozzan R., Magalhaes MEC, de Freitas EV, Brandao AP. Pulse wave velocity in young adults. Study of Rio de Janeiro. Arq Bras Cardiol. 2011;97(1).

Available:http://dx.doi.org/10.1590/S0066782X2011005000067

78. de la Grandmaison GI, Clairand I, Durigon M. Organ weight in 684 adult autopsies: New tables for a Caucasoid population. Forsciint. 2001;119:149-154.

79. Censi L, Toti E, Pastore G, Ferro-Luzzi A. The basal mesolic rate and energy cost of standardized walking of short and tall men. Eur J Clin Nutr. 1998;52:441-446.

80. Mendall MA, Strachan DP, Butland BK, Ballam L, Morris J, Sweetnam PM, Elwood PC. C-reactive protein: Relation to total mortality, cardiovascular mortality and cardiovascular risk factors in men. Eur Heart. 2000;21:1584-1590.

DOI: $10.1053 /$ cuhj.1999.1982.

81. Pannacciulli N, Cantatore FP, Minenna A, Bellacicco, Giorgino R, De Pergola G. Creactive protein is independently associated with total body fat, central fat, and insulin resistance in adult women. Int $\mathrm{J}$ Obesity. 2001;25:1416-1420.

82. Hiura M, Kiruchi T, Nagasaki K, Makoto U. Elevation of serum C-reactive protein levels is associated with obesity in boys. Hypertens Res. 2003;26:541-546.

83. Yasmin, McEniery CM, Wallace $S$, Mackenzie IS, Cockcroft JR, Wilkinson IB. C-reactive protein is associated with arterial stiffness in apparently healthy individuals. Arterioscler Throm Basc Biol. 2004;24:969-9.

84. Park HS, Park JY, Yu R. Relationship of obesity and visceral adiposity with serum concentrations of CRP, TNF-a and IL-6. Diabetes Res Clin Pract. 2005;69(1):2935.

DOI: 10.1016/j.diabres.2004.11.007.

85. Marsik C, Kazemi-Shirazi L, Schickbauer T, Winkler S, Joukhadar C, Wagner OF, Endler G. C-reactive protein and all-cause mortality in a large hospital-based cohort. Clin Chem. 2006;54(2):343-349.
86. Ahmadi-Abhari S, Luben RN, Wareham NJ, Khaw KT. Distribution and determinants of C-reactive protein in the older adult population: European Prospective Investigation into Cancer-Norfolk Study. Eur J Clin Invest. 2013;43(9):899-911.

87. Shearer E, Wideman L, Lovelady C. Changes in body composition and Creactive protein in overweight, lactating women). The FASED Journal. 2014;28(1): Supplement 247.8.

88. Lamon-Fava S, Wilson PWF, Schaefer EJ. Impact of body mass index on coronary heart risk factors in men and women. The Framingham Offspring Study. Arterioscler Thromb Vasc Biol. 1996;16:1509-1515.

89. Bellizzi MC, Dietz WH. Workshop on childhood obesity: Summary of discussion. Am J Clin Nutr. 1999;70:173S-5S.

90. Heude B, Lafay L, Borys JM, Thibult N, Lommez A, Romon M, et al. Time trend in height, weight and obesity prevalence in school children from Northern France, 1992-2000. Diabetes Metab. 2003;29:23540.

91. Tsukinoki R, Morimoto K, Nakayama K. Association between lifestyle factors and plasma adiponectin levels in Japanese men. Lipids Health Dis. 2005;2(4):27.

DOI: 10.1186/1476-511X-4-27

92. World Cancer Research Fund/American Institute of Cancer Research. Food, Nutrition, Physical Activity and the Prevention of Cancer. A Global Perspective. Washington DC: AICR. 2007; p xvii.

93. Lorenzini A. How much should we weigh for a long and healthy life span? The need to reconcile caloric restriction versus longevity with body mass index versus mortality data. Front Endocrinol; 2014.

DOI: 10.3389/fendo.2014.00121.

94. Baserga R, Prisco M, Yuan T. IGF-1 receptor signaling in health and disease. In: LeRoith D, Zumkeller W, Baxter R. (ed). Insulin-Like Growth Factors. Eurekah.com and Kluwer Academic/Plenum Publishers. 2003;104-120.

95. Hoppe C, Molgaard C, Thomsen BL, Juul $\mathrm{A}$, Michaelsen KF. Protein intake at $9 \mathrm{mo}$ of age is associated with body size but not with body fat in 10-y-old Danish children. Am J Clin Nutr. 2004;79:494-501.

96. Bartke A. Long-lived mutant, gene knockout and transgenic mice. In: Samaras TT. (ed) Human Body Size and the Laws of Scaling. Physiological, Performance, 
Growth, Longevity and Ecological Ramifications. . New York: Nova Science Publishers. 2007;191-211.

97. Switzer M, Rice J, Rice M, Hardin DS. Insulin-like growth factor-1 levels predict weight, height and protein catabolism in children and adolescents with cystic fibrosis. J Pediatr Endocrinol Metab. 2009;22(5):417-24.

98. Crow FL, Key TJ, Allen NE, Appleby PN, Overvad K, Gronbaek H, et al. A crosssectional analysis of the associations between adult height, BMI and serum concentrations of IFG-1, IGFBP-1 -2 and 3. Ann Hum Biol. 2011;38(2):194-202. DOI: 10.3109/-03014460.2010.507221.

99. Greer KA, Hughes LM, Masternak MM. Connecting serum IGF-1, body size and age in the domestic dog. Age. 2011;33(3): 475-483.

DOI: 10.1007/s11357-010-9182-4.

100. Sinaiko AR, Donahue RP, Jacobs DR, Prineas RJ. Relation of weight and rate of increase in weight during childhood and adolescence to body size, blood pressure, fasting insulin, and lipids in young adults. Circulation. 1999;99:1471-1476.

101. Goodwin PJ, Ennis M, Pritchard KI, Trudeau ME, Koo J, Madarnas Y, et al. Fasting insulin and outcome in early-stage breast cancer: Results of a prospective cohort Study. J Clin Oncol. 2001;20:42-51.

102. Cordain L, Eades MR, Eades MD. Hyperinsulinemic diseases of civilization: more than just Syndorme $X$. Comp Biochem Physiol A: Physiol. 2003;136:95112.

103. Ong KK, Petry CJ, Emmett PM, Sandhu MS, Kiess W, Hales CN, et al. Insulin sensitivity and secretion in normal children related to size at birth, postnatal growth, and plasma insulin-like growth factor-1 levels. Diabetologia. 2004;47:1064-1070. DOI: 10.1007/s00125-004-1405-8.

104. Masternak MM, Panici JA, Bonkowski MS, Hughes LF, Bartke A. Insulin sensitivity as a key mediator of growth hormone actions on longevity. J Gerontol A Biol Sci Med Sci. 2009; 64A(5):516-521.

DOI: 10.1093/gerona/glp024.

105. Cianfarani S, Holly JM, Pasquino AM, Vaccaro F, Spadoni GL, Bernardini S, et al. Insulin-like growth factor binding protein 1 (IGFBP-1) levels in Turner syndrome. Horm Metab Res. 1992;24(11):537-40.

106. Wolk K. Larsson SC, Vessby B, Wolk A, Brismar K. Metabolic, anthropometric and nutritional factors as predictors of circulating insulin-like growth factor binding protein-1 levels in middle-aged and elderly men. JCEM. 2004;89(4).

DOI.org/10.1210/jc.2003-031349.

107. Morris BJ, Willcox DC, Donlon A, Willcox BJ. FOXO3: A major gene for human longevity-A mini-review. Gerontology; 2015.

DOI: $10.11159 / 000375235$.

108. Leontieva OV, Paszkiewicz GM, Blagosklonny MV. Mechanistic mammalian target of rapamycin (mTOR) may determine robustness in young male mice at the cost of accelerated aging. Aging. 2012;4(12):899-915.

109. Blagosklonny MV. Calorie restriction: decelerating mTOR-driven aging from cells to organism (including humans). Cell Cycle. 2010;9(4):683-688.

DOI: $10.4161 / \mathrm{cc} .9 .4 .10766$.

110. Melnik BC, John SM, Plewig G. Acne: Risk indicator for increased body mass index and insulin resistance. Acta Derm Venereol. 2013;93:644-649.

111. Bottner A, Kratzsch J, Muller G, Kapellen TM, Bluher S, Keller E, et al. Gender differences of adiponectin levels develop during the progression of puberty and are related to serum androgen levels. J Clin Endocrinol Metab. 2004;89(8):4053-4061. DOI: 10.1210/jc.2004-0303.

112. Bronsky J, Nedvidkova J, Sramkova D, Pechova M, Prusa R, Nevoral J. Adiponectin, insulin and C-peptite serum levels in obese children before and after reduction of body weight: PN. 2005;1-06. JPGN 40(5):688.

113. Nakamura $\mathrm{Y}$, Ueshima $\mathrm{H}$, Okuda $\mathrm{N}$, Higashiyama A, Kita Y, Kadowaki T, et al. Relation of dietary and other lifestyle traits to difference in serum adiponectin concentration of Japanese in Japan and Hawaii: The INTERLIPiD Study. Am J Clin Nutr. 2008;88(2):424-430.

114. Hui X, Lam KSL, Vanhoutte PM, Xu A. Adiponectin and cardiovascular health: An update. Br J Pharmacol. 2012;165:574590.

Available:http://dx.doi.org/10.1111/bph.201 2.165.issue-3

115. Blaslov K, Bulum T, Zibar K, Duvnjak L. Relationship between adiponectin level, insulin sensitivity, and metabolic syndrome in Type 1 diabetic patients. Int $\mathrm{J}$ Endocrinol. 2013; article ID535906, 6 pages. 
Available:http://dx.doi.org/10.1155/2013/53 $\underline{5906}$

116. Iwabu M, Okada-Iwabu M, Yamauchi T, Kadowaki T. Adiponectin/adiponectin receptor in disease and aging. NPG $\mathrm{J}$ Aging and Mech Dis. 2015; Article number 15013(2015).

DOI:10.1038/npjamd.2015.13

117. Knight EL, Verhave JC, Spiegelman D, Hillege HL, De Zeeuw D. Curham GC. De Jong PE. Factors influencing serum cystatin $C$ levels other than renal function and the impact on renal function measurement. Kidney Int. 2004;65:14161421.

118. Woo KS, Choi JL, Kim BR, Kim JE, Han J$Y$. Clinical usefulness of serum cystatin $C$ as a marker of renal function. Diabetes Metab. 2014;38(4):278-284.

DOI: 10.4093/dmj.2014.38.4.278.

119. Bartosz G. Food toxicity contributes to the beneficial effects of calorie restriction. J Theor Biol. 2005;233(4):451-452.

120. Fishman EZ, Frank G, Efraim B-A, Kessler $G$, Pines $A$, Drory $Y$, et al. Altered left ventricular volume and ejection fraction responses to supine dynamic exercise in athletes. JACC. 1990;582-488.

DOI: 10.1016/0735-1097(90)90630-8.

121. Gallistl S, Sudi K, Mangge H, Erwa W, Borkenstein M. Insulin is an independent correlate of plasma homocysteine levels in obese children and adolescents. Diabetes Care. 2000;23:1248-135.

122. Sanlier N, Yabanci N. Relationship between body mass index and homocysteine levels in university students. JPMA. 2007;57:491-495.

123. Sadeghi O, Askari G, Maghsoudi Z, Nasiri M, Khorvash F, Ghiasvand R. Association of general obesity with hyperhomocysteinemia in patients with migraine. J Chronic Dis Care. 2015;4(1): e26596.

124. Parker DR, Lapane K, Lasater TM, Carleton RA. Int J Epidemiol. 1998;27:970975.

125. Height and heart disease: What's the connection? Kaiser Permanente researchers examine role of stature in cardiovascular disease risk. The Free Library; 2000.

126. Ro R, Murzaku EC, William M, Gadiraju S, Kersellius R, Jonnalagadda S, Majeed A, et al. MON-233: Generational differences in total and HDL cholesterol and in (Weight ${ }^{*}$ Height/HDL) of South Asian immigrants living in New Jersey. The Endocrine Society's $94^{\text {th }}$ Annual Meeting and Expo, June 23-26, 2012-Houston, TX. Presentation number: MON-233; June 25, 2012.

127. Wallwenfeldt K, Bokemark L, Wikstrand J, Hulthe J, Fagerberg B. Apolipoprotein $\mathrm{B} /$ Apolipoprotein $\mathrm{A}-1$ in relation to the metabolic syndrome and change in carotid artery intima-media thickness during 3 years in middle-aged men. Stroke. 2004; 35:2248-2252.

DOI:10.1161/01.STR.0000140629/65145.3

$\mathrm{C}$

128. Swartz W, Trost DC, Reiland SL, Rifkind BM, Heiss G. Correlates of low density lipoprotein cholesterol: Associations with physical, chemical, dietary, and behavioral characteristics. The Lipid Research Clinic Prevalence Study. Arteriosclerosis. 1982; 2:513-522.

129. O'Keefe JH, Cordain L, Harris WH, Moe RM, Vogel R. Optimal low-density lipoprotein is 50 to $70 \mathrm{mg} / \mathrm{dl}$ : Lower is better and physiologically normal. JACC. 2004;43(11):2142-2146.

DOI: 10.1016/j.jacc.2004.03.046.

130. Shirasawa $T$, Ochiai $H$, Ohtsu $T$, Nishimura $R$, Morimoto A, Hoshino $H$ et al. LDLcholesterol and body mass index among Japanese schoolchildren: A populationbased cross-sectional study. Lipids Health Dis. 2013;12(77).

DOI: 10.1186/1476-511X-12-77.

131. University of California. Adaptation to highfat diet, cold had profound effect on Inuit, including shorter height. Science Daily; 2015.

Available:www.sciencedaily.com/releases/ 2015/09/150917160034.htm

132. Brunner EJ, Wunsch H, Marmot MG. What is an optimal diet? Relationship of macronutrient intake to obesity, glucose tolerance, lipoprotein cholesterol levels and the metabolic syndrome in the Whitehall II study. Int J Obesity. 2001;25:45-53.

133. Tirosh A, Shai I, Tekes-Manova D, Israili E, Pereg D, Shochat T, et al. Normal fasting plasma glucose levels and type 2 diabetes in young men. $\mathrm{N}$ Engl $\mathrm{J}$ Med. 2005; 353:1454-62.

134. Innocent O, ThankGod OO, Sandra E, Josiah IE. Correlation between body mass index and blood glucose levels among some Nigerian undergraduates. HOAJ Biology; 2013. 
DOI: http://dx.doi.org/10.7243/2050-08742-4

135. Yajnik CS, Katre PA, Joshi SM, Kumaran $\mathrm{K}$, Bhat DS, Lubree HG, et al. Higher glucose, insulin and insulin resistance (HOMA-IR) in childhood predict adverse cardiovascular risk in early adulthood: The Pune Children's Study. Diabetologia. 2015; 58(7):1626-36.

DOI:10.1007/s00125-015-3602-z.

136. Brown DC, Byrne CD, Clark PMS, Cox BD, Day NE, Hales $C N$, et al. Height and glucose tolerance in adult subjects. Diabetologia. 1991;34(7):531-533.

137. Furer A, Afek A, Beer Z, Derazne E, Tzur $D$, Pinhas-Hamiel $O$, et al. Height at late adolescence and incident diabetes among young men. PLoS One. 2015;10(8): e0136464.

DOI: 10.1371/journal/pone.0136464.

138. Ranke MS, Schweizer R, Rodermann SM, Bevot A, Martin DD, Goetz R, et al. Schoolchildren born VLBW or VLGA show height-related changes in body composition and muscle function but no evidence of metabolic syndrome risk factors. Results from the NEOLONG study. J Pediatr Endocrinol Metab; 2015.

DOI: 10.1515/jpem-2015-0266.

139. Maple-Brown LJ, Cunningham J, Nandi N, Hodge A, O'Dea K. Fibrinogen and associated risk factors in a high-risk population: urban indigenous Australians, the DRUID Study. Caridovasc Diabetol. 2010;9(69).

DOI: 10.1185/1475-2840-9-69.

140. Hanna IR, Heeke B, Bush H, Brosius L, King-Hagerman D, Beshai JF, Langberg
JJ. The relationship between stature and the prevalence of atrial fibrillation in patients with left ventricular dysfunction. J Am Coll Cardiol. 2006;47:1683-8.

141. Rosenberg MA, Patton KK, Sotodehnia N, Karas MG, Kizer Jr, Zimetbaum PJ, et al. The impact of height on the risk of atrial fibrillation: The Cardiovascular Health Study. Eur Heart J. 2012;33(21):2709-17. DOI: 10.1093/eurheartj/ehs301.

142. Glynn RJ, Rosner B. Comparison of risk factors for the competing risks of coronary heart disease, stroke, and venous thromboembolism. Am J Epidemiol. 2005; 162(10):975-982.

DOI: 10.1093/aje/kwi309.

143. Braekkan SK, Borch KH, Mathiesen EB, Njolstad I, Wilsgaard T, Hansen J-B. Body height and risk of venous thromboembolism. The Tromso Study. Am J Epidemiol. 2010;171:1109-1115.

144. Schroder H, Marrugat J, Elosua R, Covas $\mathrm{MI}$ for the REGICOR Investigators. Relationship between body mass index, serum cholesterol, leisure-time physical activity and diet in a Mediterranean Southern-European population. Brit J Nutr. 2003;90:431-439.

145. Chmielewski $P$. The relationship between adult stature and longevity: Tall men are unlikely to outlive their short peersevidence from a study of all adult deaths in Poland in the years 2004-2008. Anthropol Rev. 2016;70:439-460.

146. Samaras TT, Storms LH. Impact of height and weight on life span. Bull World Health Organ. 1992;70(2):259-267.

(0) 2017 Samaras; This is an Open Access article distributed under the terms of the Creative Commons Attribution License (http://creativecommons.org/licenses/by/4.0), which permits unrestricted use, distribution, and reproduction in any medium, provided the original work is properly cited.

Peer-review history:

The peer review history for this paper can be accessed here: http://sciencedomain.org/review-history/20000 